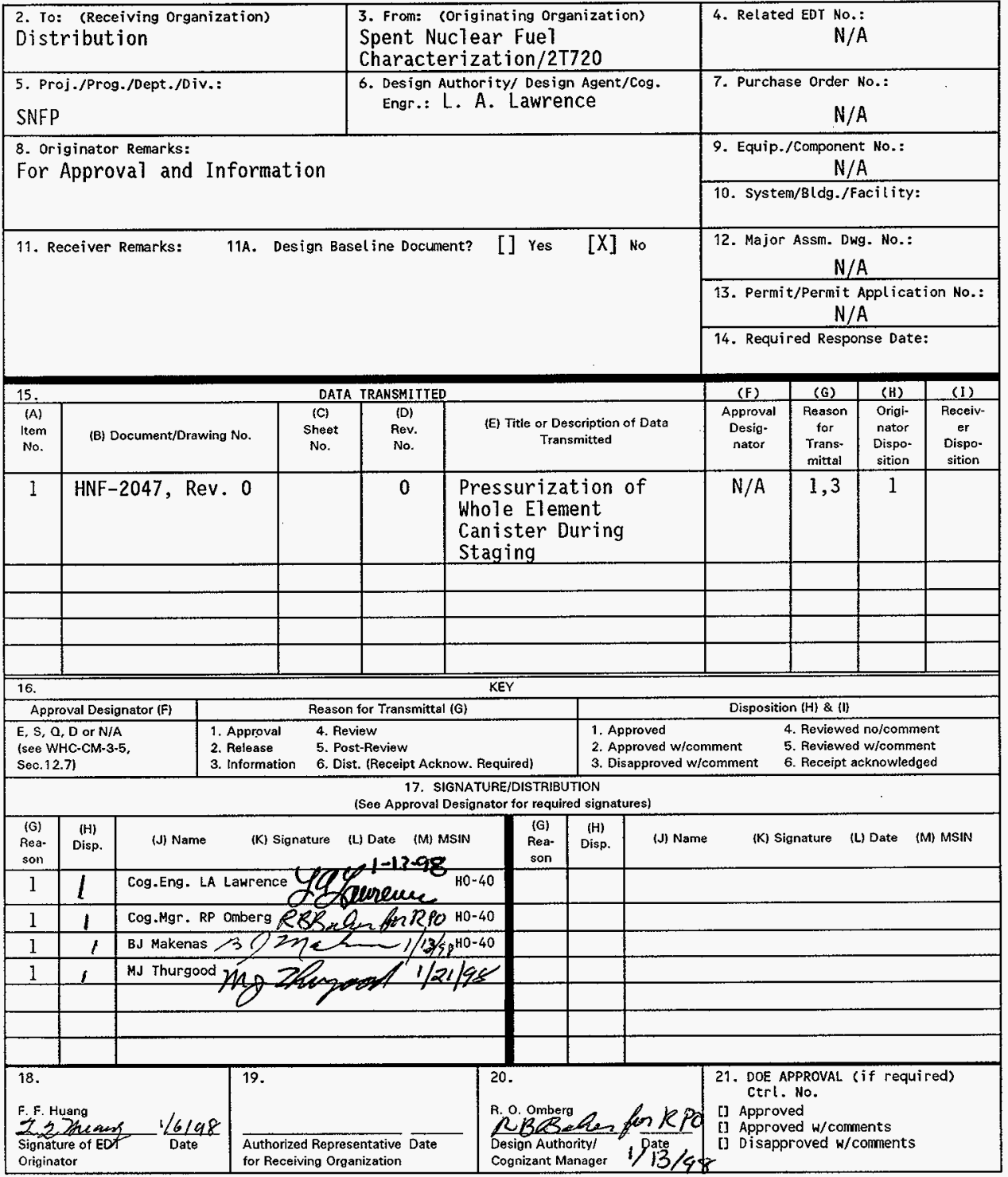


HNF-2047, Rev. 0

\title{
PRESSURIZATION OF WHOLE ELEMENT CANISTER DURING STAGING
}

\author{
F. F. Huang (FDNW), L. A. Lawrence
}

D\&ES Hanford, Richland, WA 99352

U.S. Department of Energy Contract DE-AC06-96RL13200

$\begin{array}{lll}\text { EDT/ECN: } & 615131 & \text { UC: } 2070 \\ \text { Org Code: } & 2 T 720 & \text { Charge Code: } \\ \text { B\&R Code: } & \text { EW704026 } \\ & & \text { Total Pages: } 28-38 \\ \text { yza }\end{array}$

Key Words: canister pressurization, $K$ Basin, sludge, water, hydrate

Abstract: An analytical model was developed to estimate the buildup of gas pressure for a single outer element in a hot cell test container for a post cold vacuum drying staging/storage test. This model considers various sources of gas generation and gas consumption as a function of time. In a canister containing spent nuclear fuel, hydrogen is generated from the reactions of uranium with free water or hydrated water, hydride decomposition, and radiolysis. The canister pressurization model predicts a stable pressure and a peak temperature during staging, with an assumption that a fuel element contains $40 \mathrm{gm}$ of corrosion products and a decay heat of 2.07 or 1.06 Watts. Calculations were also performed on constant temperature tests for fuel elements containing varied amounts of sludge tested at $150,125,105$, and $85{ }^{\circ} \mathrm{C}$. The pressurization model will be used to evaluate test results obtained from post-drying testing on whole fuel elements.

TRADEMARK DISCLAIMER. Reference herein to any specific comercial product, process, or service by trade name, trademark, manufacturer, or otherwise, does not necessarily constitute or imply its endorsement, recommendation, or favoring by the United States Government or any agency thereof or its contractors or subcontractors.

Printed in the United States of America. To obtain copies of this document, contact: Document Control Services, P.0. Box 950, Mailstop H6-08, Richland WA 99352, Phone (509) 372-2420; Fax (509) 376-4989.
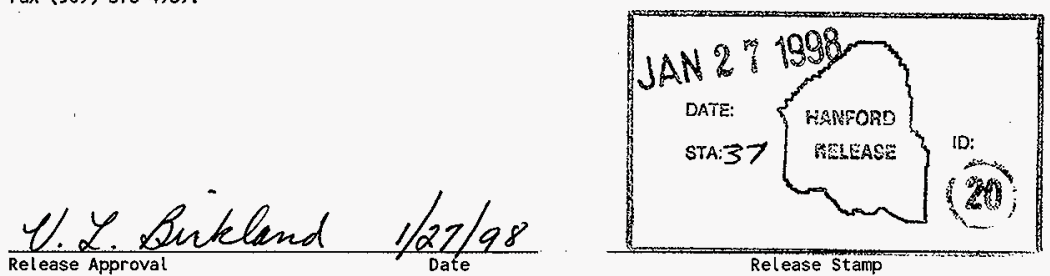
HNF-2047, Rev. 0

\section{PRESSURIZATION OF WHOLE ELEMENT CANISTER DURING STAGING}

F. F. Huang

January 1998 
HNF-2047, Rev. 0

\section{EXECUTIVE SUMMARY}

An analytical model was developed to estimate the buildup of gas pressure for a single outer element in a hot cell test container for a post cold vacuum. drying staging/storage test. This model considers various sources of gas generation and gas consumption as a function of time. In a canister containing spent nuclear fuel, hydrogen is generated from the reactions of uranium with free water or hydrated water, hydride decomposition, and radiolysis. In addition, fission product gases are released as a result of metal corrosion, however, the total volume released is small and negligible when compared to other gas sources. The temperature increase resulting from the heat balance between the gain from nuclear decay heat and exothermic chemical reactions involving uranium metal and the loss to the surroundings of the fuel canister was calculated. The increase in temperature leads to the increase in pressure as gas generation in each source mentioned above increases with temperature. Some of the gases generated may chemically recombine with fuel and cladding materials. In this analysis all oxygen is assumed to react with uranium and hydrogen recombination as hydride is neglected.

The canister pressurization model predicts a stable pressure of about 21 psig in 25 days and a peak temperature of $73^{\circ} \mathrm{C}$ at 40 hours during testing, with an assumption that a fuel element contains $40 \mathrm{gm}$ of corrosion products and a decay heat of $2.07 \mathrm{~W}$. For a fuel element with a lower decay heat, $1.06 \mathrm{~W}$, the model predicts that the pressure reaches $21 \mathrm{psig}$ in 50 days and continues to increase slightly. Calculations were also performed on 
HNF-2047, Rev. 0

constant temperature tests in which the temperature was increased at a rate of $0.5^{\circ} \mathrm{C} / \mathrm{min}$ to constant temperatures; the pressures in the whole element canister were found to level off in 1, 4, 12, and 40 days for fuel elements containing $20 \mathrm{gm}$ or $40 \mathrm{gm}$ of sludge tested at $150{ }^{\circ} \mathrm{C}, 125{ }^{\circ} \mathrm{C}, 105^{\circ} \mathrm{C}$, and $85^{\circ} \mathrm{C}$, respectively. The pressurization model will be used to evaluate test results obtained from post-drying testing on whole fuel elements. 


\section{CONTENTS}

1.0 INTRODUCTION ......................... 5

2.0 PRESSURIZATION MODEL . . . . . . . . . . . . 7

2.1 GAS GENERATION . . . . . . . . . . . . . 7

2.1.1 Water/Uranium Chemical Reaction ......... 7

2.1.2 Hydride Decomposition ............. 8

2.1.3 Hydrate Decomposition . . . . . . . . . . . . 8

2.1 .4 Radiolysis of Water ................... 11

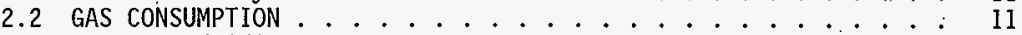

2.2 .1 Hydriding ......................... 11

2.2 .2 oxygen Gettering . . . . . . . . . I1

2.3 FUEL SURFACE AREA AND CANISTER FREE VOLUME $\ldots . . . . .11$

2.4 HEAT GAIN AND LOSS . . . . . . . . . . . . . . . 12

3.0 CALCULATIONS . . . . . . . . . . . . . . . 13

4.0 WHOLE ElEMENT TESTING . . . . . . . . . . . . 15

5.0 DISCUSSION . . . . . . . . . . . . . . . . . 17

5.1 ASSUMPTIONS . . . . . . . . . . . . . . . . . . . 17

5.2 GAS GENERATION $\ldots . \ldots . . . \ldots 18$

5.3 MODELING AND VERIFICATION . . . . . . . . . . . 18

6.0 CONCLUSION . . . . . . . . . . . . . . . 21

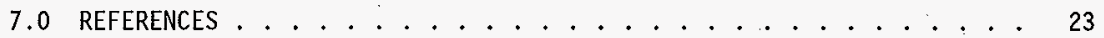




\section{LIST OF FIGURES}

1. Canister Pressure During Staging for a Fuel Element with $40 \mathrm{gm}$ of. STudge and Decay Heat of 2.07 Watts . . . . . . . . . 25

2. Canister Pressure During Staging for a Fuel Element with $40 \mathrm{gm}$ of Sludge and Decay Heat of 1.06 Watts . . . . . . . 26

3. Canister Temperature During Staging for a Fuel Element with $40 \mathrm{gm}$ of Sludge and Decay Heat of 2.07 Watts . . . . . . . 27 .

4. Canister Temperature During Staging for a Fuel Element with $40 \mathrm{gm}$ of Sludge and Decay Heat of 1.06 Watts . . . . . . 28

5. A Comparison Between Canister Pressures at Constant Temperatures of $85^{\circ} \mathrm{C}$ for $40 \mathrm{gm}$ and $20 \mathrm{gm}$ Sludge Contents .....

6. A Comparison Between Canister Pressures at Constant Temperatures of $85^{\circ} \mathrm{C}$ for $10 \mathrm{gm}$ and $5 \mathrm{gm}$ Sludge Contents . . . . . 30

7. A Comparison Between Canister Pressures at Constant Temperatures of $105{ }^{\circ} \mathrm{C}$ for $40 \mathrm{gm}$ and $20 \mathrm{gm}$ Sludge Contents . . . . . 31

8. A Comparison Between Canister Pressures at Constant Temperatures of $105{ }^{\circ} \mathrm{C}$ for $10 \mathrm{gm}$ and $5 \mathrm{gm}$ S1udge Contents. . . . . 32

9. A Comparison Between Canister Pressures at Constant Temperatures of $125^{\circ} \mathrm{C}$ for $40 \mathrm{gm}$ and $20 \mathrm{gm}$ Sludge Contents.....

10. A Comparison Between Canister Pressures at Constant Temperatures of $125^{\circ} \mathrm{C}$ for $10 \mathrm{gm}$ and $5 \mathrm{gm}$ Sludge Contents . . . . 34

11. A Comparison Between Canister Pressures at Constant Temperatures of $150^{\circ} \mathrm{C}$ for $40 \mathrm{gm}$ and $20 \mathrm{gm}$ Sludge Contents . . . .

12. A Comparison Between Canister Pressures at Constant Temperatures of $150{ }^{\circ} \mathrm{C}$ for $10 \mathrm{gm}$ and $5 \mathrm{gm}$ STudge Contents......

\section{LIST OF TABLES}

1. Key Parameters for Canister Pressure Mode1 . . . . . . . . . . . 14

2. Particulate Mass .................. . 18 
HNF-2047, Rev. 0

\section{PRESSURIZATION OF WHOLE ELEMENT CANISTER DURING STAGING}

\subsection{INTRODUCTION}

The highly radioactive fuel in the $\mathrm{K}$ Basins is to be removed and stored in the 200 East area. The spent nuclear fuel (SNF) will be loaded in specially designed containers, called multi-canister overpack (MCO), and transported from the basins to a staging area for stabilization and dry storage based on the approach established in the SNF Projects. Integrated Process Strategy (IPS) (WHC 1995). Preparation of whole fuel element testing is underway to provide data to support preparation of the safety analysis report and the process design for the IPS (Lawrence 1997a).

Following drying in the whole element furnace, selected damaged fuel elements that were retrieved from the $\mathrm{K}$ West Basin will be monitored for pressure and temperature. The pressure in the container holding SNF will increase because of gas generation from the following sources: hydrogen generated from the reactions of uranium with free water or hydrated water, hydrogen generated from hydride decomposition, hydrogen and oxygen generated from water radiolysis, and fission product gases generated from metal corrosion. Volumes of fission gases are small and are assumed to be negligible compared to other gas sources. The temperature in the fuel canister also will increase because of nuclear decay heat and exothermic chemical reactions involving uranium metal. As part of 7 aboratory testing preparation, pressurization analysis for the whole fuel element canister is undertaken to establish test parameters. Laboratory testing will control the temperature and monitor gas generation, i.e., pressure with time. Gas samples will also be removed periodically for composition analysis.

Modeling calculations predict the pressure buildup of the planned single element post cold vacuum drying (CVD) test and provide a basis for post-test evaluation of the test data. Results from these whole element tests will provide data for benchmarking the computer modeling of MCO pressurization (Fryer 1996) which uses COBRA-TF and GOTH codes to simulate thermal and pressure response of the MCO to various events that may occur during fuel processing and storage. 
HNF-2047, Rev. 0

This page intentionally left blank. 


\subsection{PRESSURIZATION MODEL}

The bulk of the free water in the whole element canister is expected to be removed in the cold vacuum drying (CVD) process. However, there exists a smal1 quantity of free water in crystal defects within the oxide lattice, chemically bound water in hydrates such as $\mathrm{Al}_{2} \mathrm{O}_{3} \cdot 3 \mathrm{H}_{2} \mathrm{O}$, $\mathrm{Fe}_{2} \mathrm{O}_{3} \cdot \mathrm{H}_{2} \mathrm{O}$, and $\mathrm{UO}_{3} \cdot 2 \mathrm{H}_{2} \mathrm{O}$, chemically bound hydroxides that form at the surface of uranium oxide $\left(\mathrm{UO}_{2}\right)^{2}$ and may migrate into the oxide lattice. All of these species determine the partial pressure of water in the canister. The partial pressure of water from uranium hydroxide $(\mathrm{UOH})$ is insignificant as it is bonded very strongly to the oxide surface and can only be removed at temperatures as high as $800^{\circ} \mathrm{C}$.

The chemical gas generation rate depends on the partial pressure of water vapor and the temperature. If all free water is removed after CVD, the partial pressure of water vapor is expected to be decreased to 1 torr $(0.1333 \mathrm{kPa})$. Gas generation is also caused by decompositions of hydride and hydrates and radiolytic decomposition of water.

Four pressure units (torr, $\mathrm{kPa}$, atm, and psig) are used in different. equations relating pressure to temperature. All units are converted to torr in calculations. Results are plotted as $P(p s i g)$ in terms of time where $P($ psig $)=P($ torr $) \times 0.019334$.

\subsection{GAS GENERATION}

\subsubsection{Water/Uranium Chemical Reaction}

The reaction rate equation determined in oxygen-free atmosphere and $100 \%$ relative humidity (R. H.) is used to estimate the uranium corrosion rate (Pearce 1989).

$$
\begin{array}{llrl}
\log K=7.364-3016 / T & & \text { for } T<373 K \\
\log K=4.33-2144 / T+0.5 \log P & & \text { for } T<523 K
\end{array}
$$

where:

$\mathrm{K}$ is in $\mathrm{mg}-\mathrm{O}_{2} / \mathrm{cm}^{2}-\mathrm{hr}, \mathrm{T}$ in $\mathrm{K}$, and $\mathrm{P}$ in $\mathrm{kPa}(\mathrm{P}($ torr $)=\mathrm{P}(\mathrm{kPa}) \times 0.1333)$

Weight gain in moles $\mathrm{O}_{2} / \mathrm{hr} / \mathrm{cm}^{2}=10 \times \mathrm{K} / 32000 \mathrm{mg} / \mathrm{gmole}$

Moles $\mathrm{H}_{2} / \mathrm{hr} / \mathrm{cm}^{2}=2 \times 10 \times \mathrm{K} / 32000$

The hydrogen generation rate of uranium corrosion can be determined if the fuel surface area is known. Temperature increase is determined from heat generated during uranium-water and uranium-oxygen reactions and decay heat. 


\subsubsection{Hydride Decomposition}

Hydrogen will be released from hydrides if the fuel temperatures are sufficientiy high, but it will react with uranium again to form hydrides if the hydrogen concentration becomes sufficiently high. The equilibrium hydrogen pressure $\mathrm{P}_{0}$ in torr at temperature $T$ in $\mathrm{K}$ is given by

$$
P_{0}=10^{-A / T+B}
$$

where:

$$
\begin{aligned}
& A=3473, B=8.05 \text { for hydriding } \\
& A=4700, B=9.47 \text { for dehydriding }
\end{aligned}
$$

The extent of reaction is given by (Duncan 1997)

$$
\begin{aligned}
& \alpha=92.833 t \ln \left(P_{0} / P\right) e^{-9524.67 / T} \text { for hydriding } \\
& \alpha=A \cdot t \ln \left(P_{0} / P\right) e^{-9535.82 / T} \text { for dehydriding }
\end{aligned}
$$

where:

$$
\begin{aligned}
& \alpha=\text { Fraction of hydride mass decomposed or previously hydrided uranium } \\
& \text { that can be rehydrided } \\
& P=\text { Partial pressure of hydrogen in the gas surrounding the fuel in torr } \\
& a=5570 / \mathrm{min} ; t=\text { time }
\end{aligned}
$$

For dehydriding process the hydrogen concentration will continuously increase until it reaches the equilibrium concentration which will be changing with changing fuel temperature. Hydrides are found in sludge as well as damaged fuel surfaces. The total hydride in one $\mathrm{kg}$ of siudge is assumed to be 90 grams (Cooper 1996). With 3.5 moles of hydrogen produced for each mole of uranium hydride reacted, the maximum amount of hydrogen generated from hydride is $1.31(90 \times 3.5 / 241)$ moles $\mathrm{H}_{2} / \mathrm{kg}$ sludge.

According to Equation 3, the hydrogen dissociation pressure is 19 torr at $300{ }^{\circ} \mathrm{C}$. The pressure decreases as the temperature decreases. Because whole element testing wi11 be performed at temperatures lower than $300{ }^{\circ} \mathrm{C}$ and the hydrogen pressure due to uranium chemical reactions is likely to be higher than the hydrogen dissociation pressure, the hydrogen generation from dehydriding is expected to be insignificant.

\subsubsection{Hydrate Decomposition}

The three hydrates, $\mathrm{Al}_{2} \mathrm{O}_{3} \cdot 3 \mathrm{H}_{2} \mathrm{O}, \mathrm{Fe}_{2} \mathrm{O}_{3} \cdot \mathrm{H}_{2} \mathrm{O}$, and $\mathrm{UO}_{3} \cdot 2 \mathrm{H}_{2} \mathrm{O}$, are found to be associated with fuel elements. Because their vapor pressures are larger than the pressure in the cold vacuum drying process, part of the waters of hydration is expected to be released. The contaminant aluminum and iron oxides will be removed by the cleaning process, only uranium oxides adhere to 
the uranium metal (Cooper 1996). The calculations consider the decomposition of uranium hydrate only. If other hydrates are not negligible, their decomposition rates will need to be established experimentally for pressurization calculations.

Based on experimental data (Abrefah 1997) a first-order law is selected to describe the rate of hydrate decomposition (Plys 1997) for a three-step hydrate decomposition process:

Step 1

$$
\mathrm{UO}_{3} \cdot 2 \mathrm{H}_{2} \mathrm{O} \rightarrow \mathrm{UO}_{3} \cdot \mathrm{H}_{2} \mathrm{O}
$$

Step 2

$$
\rightarrow \mathrm{UO}_{3} \cdot \frac{1}{2} \mathrm{H}_{2} \mathrm{O}
$$

Step 3

$$
\rightarrow \mathrm{UO}_{3}
$$

The Arrhenius rate equations are given by

$$
k_{i}=e^{(A i-Q i / T)}
$$

where:

$$
\begin{aligned}
i & =\text { Step } 1,2, \text { and } 3 \\
k_{i} & =\text { Weight loss fraction per minute for step } i \\
T & =\text { Temperature in } \mathrm{K} \\
Q_{1} & =Q_{2}=Q_{3}=8000 \mathrm{~K} \\
A_{1} & =15.12 \text { for first step } \\
A_{2} & =11.93 \text { for second step } \\
A_{3} & =10.067 \text { for third step }
\end{aligned}
$$

First order weight loss rates are assumed in the following equations:

$$
\begin{aligned}
& d u_{1} / d t=-k_{1} u_{1} \\
& d u_{2} / d t=k_{1} u_{1}-k_{2} u_{2} \\
& d u_{3} / d t=k_{2} u_{2}-k_{3} u_{3}
\end{aligned}
$$


where:

$u_{i}$ is the mass fraction of hydrate at step $i$ and $k_{i}$ is dependent on temperature which changes with time, the solution of Equation 6 is found to be

$$
u_{1}=e^{-\int_{t} k_{1}[T(t)] d t}
$$

The integral in Equation 10 can be solved numerically for approximation. If the temperature is assumed to be constant for a period of time, $\int k_{1} d t=k_{1} t$. Once $u_{1}$ and $k_{1}$ are determined, the mass fraction $u_{2}$ in Step 2 can be obtained by solving the differential Equation 8 .

$$
\begin{aligned}
& \text { In }\left(k_{1} u_{1}-k_{2} u_{2}\right)=-\int k_{2} d t+c \\
& u_{2}=k_{1} u_{1} / k_{2}-c e^{-1 k_{2} d t}
\end{aligned}
$$

where:

$c$ is determined from the initial condition: $u_{2}(0)=u_{1}$

$$
c=k_{1} u_{1} / k_{2}-u_{1}
$$

thus,

$$
u_{2}=k_{1} u_{1} / k_{2}\left(1-e^{-j k_{2} d t}\right)+u_{1} e^{-j k_{2} d t}
$$

Similarly,

$$
u_{3}=k_{2} u_{2} / k_{3}\left(1-e^{-1 k_{3} d t}\right)+u_{2} e^{-l k_{3} d t}
$$

Decomposition of hydrate in each step proceeds until the partial pressure of water vapor in the gas increases to the levels of the hydrate's equilibrium pressures $\left[P_{i}\right.$ in atm, $P($ torr $\left.)=P(a t m) \times 760\right]$ for each step given below (Plys 1997):

$$
P_{i e}=e^{B i+D i / T}
$$

where:

$$
\begin{aligned}
& \mathrm{B}_{1}=15.912, \mathrm{D}_{1}=-6131 \text { for } \mathrm{UO}_{3} \cdot 2 \mathrm{H}_{2} \mathrm{O} \\
& \mathrm{B}_{2}=18.382, \mathrm{D}_{2}=-7766 \text { for } \mathrm{UO}_{3} \cdot \mathrm{H}_{2} \mathrm{O} \\
& \mathrm{B}_{3}=18.408, \mathrm{D}_{3}=-8488 \text { for } \mathrm{UO}_{3} \cdot \frac{1}{2} \mathrm{H}_{2} \mathrm{O}
\end{aligned}
$$


In an MCO containing $145 \mathrm{~kg}$ of sludge for the bounding conditions, the weight of water in $\mathrm{UO}_{3} \cdot 2 \mathrm{H}_{2} \mathrm{O}$ is estimated to be $14.5 \mathrm{~kg}$ or $54 \mathrm{gm}$ per element (Duncan 1997). This estimate is quite high in comparison to that from fuel element sampling campaign. Elements selected for post CVD pressure testing have damage that is comparable to the elements destructively examined for subsurface sludge. The maximum quantity of particulate collected from a damaged $\mathrm{K}$ West element was $20 \mathrm{gm}$ (Pitner 1997). A maximum value of $40 \mathrm{gm}$ was selected for the parametric calculations to be sure and bracket the observed particulate inventories expected in the damaged $K$ West element for these tests. The pressurization mode 7 assumes s7udge contents of $5 \mathrm{gm}, 10 \mathrm{gm}$, $20 \mathrm{gm}$, and $40 \mathrm{gm}$ for a whole fuel element and that $10 \%$ of the sludge is water.

\subsubsection{Radiolysis of Water}

The hydrogen generation rate due to radiolysis during CVD and staging was estimated to be $9.688 \times 10^{-9} \mathrm{~mol} / \mathrm{s}$ for a MCO with $145 \mathrm{~kg}$ of s7udge and a thin molecular film of surface water $(0.0283 \mathrm{gm})$ (Cooper 1996). The sludge was assumed to contain $10 \%$ water in volume. Surface absorbed water contributes little to water vapor partial pressure, however, they are subjected to radiolysis. The amount of radiolytic hydrogen generated in the single element canister is expected to be insignificant during staging.

\subsection{GAS CONSUMPTION}

\subsubsection{Hydriding}

As discussed in Section 2.1.2, hydrogen will react with uranium and form hydrides though the availability of uranium for the reaction is uncertain. For conservatism, hydrogen recombination as hydride is neglected in the analysis.

\subsubsection{0xygen Gettering}

Low oxygen levels needed to be maintained to minimize the detonation potential of hydrogen by use of oxygen gettering materials such as carbon steel. In this analysis all oxygen is assumed to react with uranium.

\subsection{FUEL SURFACE AREA AND CANISTER FREE VOLUME}

The fue 1 surface area in an MCO has been estimated and reported (Lawrence 1997b). For each fuel element, the geometric cross sectional area of an outer element is $a_{0}=15 \mathrm{~cm}^{2}$, and that of an inner element is $a_{i}=7.2 \mathrm{~cm}^{2}$. Area factors were assigned for four general areas of damaged fuel on the basis of visual examinations (Pitner 1995). The "worst case" corroding surface areas for one damaged fuel element is estimated: area factors 0.01 for incipient, 0.25 for rupture, 1 for 100 se end cap, 17 for split cladding of outer element, and 14 for inner element. Only the outer fuel element will be placed in the canister for testing, the total surface area $(15 \times 18.26)$ of the damaged fuel is $274 \mathrm{~cm}^{2}$. 
The outer element volume of type "M" Mark IA fuel element is $901 \mathrm{~cm}^{3}$, the free volume in a canister is $4400 \mathrm{~cm}^{3}$.

\subsection{HEAT GAIN AND LOSS}

Temperature needs to be determined and used to calculate uranjum-water reactions, hydrate decomposition, dehydriding, and radiolytic reaction. The temperature in the canister will increase as a result of heat gained from nuclear decay heat and chemical reactions. Decay heat for each fuel assembly is estimated to range from 0.53 to $4.82 \mathrm{~W}$ with a nominal load of $1.58 \mathrm{~W}$ (1.06 W for an outer element). This wide range of decay heat presents an uncertainty in predicting temperature and thus gas generation.

The temperature inside the canister is higher than that in the environment, some of the heat gained from nuclear decay and chemical reactions is expected to dissipate into the surroundings of the canister. Since the temperature difference between the canister and its surroundings is not too large, the lumped capacitance method is used to evaluate the rate of heat transfer. The total rate of heat transfer by conduction, convection, and radiation is approximately proportional to the temperature difference $(\Delta \mathrm{T})$. The heat flow at time $\mathrm{t}$ is

$$
q_{t}=h S \Delta T e^{-N B I N F O}
$$

where:

$$
\begin{aligned}
h & =\text { Surface film coefficient in } \mathrm{W} / \mathrm{m} \cdot \mathrm{K} \\
\mathrm{S} & =\text { Surface area } \\
\mathrm{N}_{\mathrm{Bi}} & =\mathrm{hL} / \mathrm{K}, \text { Biot number } \\
\mathrm{L} & =\mathrm{V} / \mathrm{S}, \text { characteristic length } \\
\mathrm{K} & =\text { Thermal conductivity in } \mathrm{W} / \mathrm{m} \cdot \mathrm{K} \\
\mathrm{N}_{\mathrm{Fo}} & =\mathrm{kt} /\left(\rho \mathrm{cL}^{2}\right), \text { Fourier number } \\
\rho & =\text { Density } \\
\mathrm{c} & =\text { Specific heat }
\end{aligned}
$$

The heat loss calculated from Equation 14 is accounted for in evaluating the temperature in the canister at time $t$. After the CVD, the fuel particulates inside the canister will release water from hydrates. The water vapor will react with uranium metal or hydrides to produce heat, the temperature increases rapidly until the water vapor is depleted. Although nuclear decay heat is continuously generated, the heat loss to the surroundings causes the temperature to decrease. 


\subsection{CALCULATIONS}

The calculations start with an initial water vapor pressure of 3 torr and a temperature of $50^{\circ} \mathrm{C}$ in $1 \mathrm{~atm}$ helium environment after cold vacuum drying is completed. The model considers free water, if any, and water released from hydrate decomposition. The water reacts with uranium metal to produce hydrogen with a generation rate given in Equation 1 for cases of temperatures lower or higher than $100^{\circ} \mathrm{C}$. The amount of hydrogen produced is limited to the total quantity of water available. In constant temperature tests, the fuel element in the canister is heated to decompose hydrates to produce both water vapor and hydrogen.

Hydrate decomposition rates are calculated from Equation 6 with constants determined experimentally. Based on these rates, the mass loss fractions are obtained from Equations 7 through 12 for the 3-step hydrate decomposition process. The decomposition will stop if the partial pressure of water vapor is higher than the hydrate's equilibrium pressures given in Equation 13 until high temperatures are attained. The calculations show that dihydrate completes decomposition first and temperature has a strong effect on the rates of the three decomposition steps.

The hydrogen generated from dehydriding is also calculated, but because the hydrogen dissociation pressure is fairly low even at $300{ }^{\circ} \mathrm{C}$, little hydrogen pressure is expected from hydride decomposition during staging. Hydrogen generated from radiolysis of water is included in the model but again the slow generation rate produces only an insignificant amount of hydrogen in such a short period of time during staging.

In addition to chemical reaction heat, decay heat constantly contributes to the temperature increase in the canister and thus to the hydrogen generation. Heat loss to the surroundings (Equation 14) reduces the temperature increase and causes temperature to decline after the exothermic chemical reaction slows down. For constant temperature tests, the pressure is calculated in an increment of 10 minutes with a furnace temperature ramp of $0.5{ }^{\circ} \mathrm{C} /$ minutes; the calculations are then changed to an increment of 1 hour as the pressure becomes stable. Pressure-time results are obtained at four constant temperatures $\left(85,105,125\right.$, and $\left.150^{\circ} \mathrm{C}\right)$ with various sludge contents.

Input parameters for the pressurization model are listed in Table 1. Most of the input data are from the SNF Project Databook (Duncan 1997). The input parameters shown in Table I are scaled for the outer element only. Preliminary: results for the predicted pressure behavior in the single fuel element canister during staging are shown in Figures 1 and 2 for decay heat of $2.07 \mathrm{~W}$ (bounding condition for an outer element) and $1.06 \mathrm{~W}$, respectively. It takes 25 or 50 days for the pressure to reach a stable level of about 21 psig depending on the assumed decay heats. 
Table 1. Key Parameters for Canister Pressure Model.

\begin{tabular}{||l|l|l||}
\hline \multicolumn{1}{|c|}{ Parameter } & \multicolumn{1}{|c|}{ Value } & \multicolumn{1}{c||}{ Reference } \\
\hline Decay heat & $2.07,1.06 \mathrm{~W}$ & HNF-SD-SNF-TI-015 \\
\hline Fuel reaction area & $274 \mathrm{~cm}^{2}$ & HNF-SD-SNF-CN-017 \\
\hline Reaction rate multiplier & 10 & HNF-SD-SNF-TI-015 \\
\hline Free volume & $4400 \mathrm{~cm}^{3}$ & \\
\hline Sludge & $40 \mathrm{gm}, 20 \mathrm{gm}, 10 \mathrm{gm}, 5 \mathrm{gm}$ & HNF-SD-SNF-TI-060 \\
\hline Water fraction & $10 \%$ & HNF-SD-SNF-TI-015 \\
\hline Water bath temperature & $50^{\circ} \mathrm{C}$ & \\
\hline
\end{tabular}

As the heat in the canister increases by decay heat, the pressure increases slowly at first. The chemical reactions begin to rise and contribute a significant amount of heat; the increase in temperature then accelerates the chemical reactions and causes a rapid increase in pressure as shown in the transient phase in Figures 1 and 2 . The pressure behavior in this phase primarily depends on the uranium-water reaction kinetics, the water release rate, and fuel surface area.

While surface water reacts with uranium, water is also released from hydrates which are gradually depleted. Water vapor pressure can influence the chemical reactions of uranium which contribute to temperature increase. The increase in pressure eventually ends when all waters of hydration are depleted. The temperature increase also ends because nuclear decay and chemical heats transfer to the environment. Figures 3 and 4 show the temperature profiles as a function of time. The temperature in the whole element canister peaks at $73{ }^{\circ} \mathrm{C}$ in 40 hours during staging then declines as the water is exhausted for the fuel element with decay heat of $2.07 \mathrm{~W}$. Figure 4 shows that the temperature peaks at $62{ }^{\circ} \mathrm{C}$ in 52 hours for the fuel element with decay heat of $1.06 \mathrm{~W}$.

Whole element testing also will be performed at constant temperatures. The pressure in the canister will be monitored for each test temperature. With the temperature maintained constant, the pressure is expected to level off as the water released from fuel and sludge are continuousiy depleted. The temperature at plateau is dependent on the sludge content in the fuel element. Pressure-time plots at $85^{\circ} \mathrm{C}, 105^{\circ} \mathrm{C}, 125^{\circ} \mathrm{C}$, and $150^{\circ} \mathrm{C}$ predicted by the pressurization model are shown in Figures 5 through 12 which shows that the pressure in the canister increases with increasing temperature. The. maximum pressure in the canister having a higher sludge content is higher than that of the canister containing less sludge. "The model also predicts that the pressure in the fuel canister staged at $85^{\circ} \mathrm{C}$ will level off in a much longer time than staging at $105^{\circ} \mathrm{C}$ or higher temperatures. 
HNF-2047, Rev. 0

\subsection{WHOLE ELEMENT TESTING}

A testing facility for post-drying staging tests will be setup. Samples will be removed from the whole element drying and conditioning furnace and placed directly into the test container. The pressure and temperature in the container will be monitored. Constant temperature tests also will be conducted to evaluate the pressure increase in the canister at temperature.

The heating and gas pressure ranges will be from room temperature to $150{ }^{\circ} \mathrm{C}$ and from $0.5 \mathrm{~atm}$ to $5 \mathrm{~atm}$, respectively. Periodically, sma11 gas samples of about $10 \mathrm{ml}$ will be extracted from the fuel container for composition determination. 
HNF-2047, Rev. 0

This page intentionally left blank. 
HNF-2047, Rev, 0

\subsection{DISCUSSION}

If heat in the canister is generated faster than it can be dissipated, a pressure-temperature excursion may occur during the staging period. The pressure and temperature in a single fuel element canister are calculated based on the generation of hydrogen and heat from various sources. Analysis shows that the increase in pressure and temperature is closely related to the fuel reaction area and the amount of water present in the canister. Since the accuracy of predicted pressure and temperature depends on the assumptions of water contents in the fuel container, experimental results should provide useful data to validate the computer modeling. The significance of water content estimate, gas generation, and experimental verification for pressurization modeling is discussed below.

\subsection{ASSUMPTIONS}

The amounts of water content and fuel damage are the factors that determine whether the MCO will be over-pressurized during shipping, staging and storage. The numerical values of these factors have to be assumed as input data for pressurization models. With these assumptions the computer modeling can predict whether or how long. it will take for over-pressurization to occur under various operation conditions. Results of modeling witl not be accurate if the assumptions are incorrect. Therefore, all assumptions concerning the pressure and temperature in a container containing SNF should have sound and justifiable basis; they should be verified by experimental data, if possible.

The sludge inventory estimates have been recentiy revised incorporating newly available information on character of fuel and scrap (Pajunen 1997), sludge density, water fraction (Makenas 1997), cladding surface $f i l m$, and fuel assembly examinations (Pitner 1997). Visual evidence was used to assume locations holding particulate, the characteristic dimensions of particulate were assigned based on measurements, and particulate was assumed to be generated during queuing for transfer. With these assumptions the calculations consider corrosion product, particulate, and visible layers for their masses and potential contents of chemically bound water. Sources of corrosion product and particulate include visible layers on cladding, oxide layers on scrap and fuel, particulate on scrap and fuel, and particulate generated by oxidation after the MCO is loaded and waiting for shipping.

Bounding estimate, best-estimate, and low values were calculated for each of the following parameters in order to determine particulate mass for each source mentioned above: mass per area, oxidation area of scrap and fuel, density and thickness of oxide Tayer, mass of particulate per assembly in scarp and fuel baskets (Sloughter 1997). The total values of derived particulate mass estimated are Tisted in Table 2. ATso 1isted in the table is the particulate mass for one fuel element assuming an MCO contains 270 elements. The best-estimate of particulate mass is $29 \mathrm{gm}$ for a single element. Calculations are performed to show the pressure 1 imits for a whole element that may contain $40 \mathrm{gm}, 20 \mathrm{gm}, 10 \mathrm{gm}$, or $5 \mathrm{gm}$ of corrosion products. 
HNF-2047, Rev. 0

Table 2. Particulate Mass.

\begin{tabular}{|l|l|l|l|}
\hline \multicolumn{1}{|c|}{ Mass } & \multicolumn{1}{|c|}{ Bounding } & Best-Estimate & \multicolumn{1}{c|}{ Low } \\
\hline MC0 Particulate mass (gm) & 58,000 & 7,700 & 2,100 \\
\hline Whole element particulate mass (gm) & 215 & 29 & 8 \\
\hline
\end{tabular}

\subsection{GAS GENERATION}

After cold vacuum drying, water will still be released from sludge or from hydrate decomposition. Chemical reactions of water with uranium generate hydrogen and heat. Hydrogen is also generated from dehydriding and radiolysis of water, but as mentioned previously dehydriding is not active when temperature is lower than $300^{\circ} \mathrm{C}$, thus, contributions to hydrogen generation from dehydriding during staging is not expected to be significant. Radiolysis of water also contributes little to gas generation because the radiolytic rate is small, it will take a long time to make gas generation significant. All of the above four sources are modeled to calculate the hydrogen generation rate in the canister.

Because sludge has a porous structure and poor heat conductivity water is difficult to remove from sludge by vaporization. The amount of water that is retained in sludge after cold vacuum drying has to be evaluated for computer modeling. All hydrates in sludge cannot be removed by the vacuum drying at $50{ }^{\circ} \mathrm{C}$ although such removal is possible if the temperature is increased for hot vacuum drying. Therefore, pressurization modeling also requires inputs of estimated hydrate weight. Clearly, sludge behavior concerning water inventories is influential in achieving accurate prediction for the pressure and temperature in the fuel canisters.

\subsection{MODELING AND VERIFICATION}

Pressurization modeling is based on the generation of hydrogen resulting from the reaction of uranium and water. Both free water and the water decomposed from uranium corrosion product (sludge) contribute to MCO pressurization. Apparently, the amount of sludge in the fuel container is one of the key parameters for modeling the pressure in the container. Since some of the SNF elements at Hanford are corroded, the sludge inventory in the fuel is difficult to evaluate accurately. Efforts have been made to examine the single fuel elements and estimate the weight of sludge for whole fuel elements (Pitner 1997). Experimental measurements on other modeling parameters such as reaction surface area and decay heat are desirable. The whole fuel element testing is expected to verify the following.

- Free Water: The present mode1 assumes no free water in the whole element canister after CVD. In the CVD process, the free water begins to boil as the pressure in the vacuum system decreases to the partial pressure of water at the MCO temperature. It then cools 
rapidly and is removed unti $i$ equilibrium pressure and temperature are reached. Because the $M C 0$ contains 270 elements placed in five or six baskets, its internal structure is much more complicated than that of the whole element furnace being used to dry elements in the laboratory and more time may be required in the CVD process to remove free water completely from the $M C 0$. If the CVD is not capable of removing $100 \%$ of the free water from the MCO, then some amount of free water may need to be assumed in the pressurization model as the contributions to the pressure increase by free water in the fuel container cannot be ignored.

- Sludge Content: Sludge is a source of free water, chemically bound water, and hydrogen in the MCO. The assumed or estimated weight of sludge in the pressurization modeling will be checked by performing whole element testing. If all of the water released from sludge react with uranium, the total pressure of water vapor and hydrogen should be close to the equivalent amount of water in sludge retained by the fuel. The content of sludge directly affects the safety of SNF storage; therefore, sludge content estimate must be objective and be supported by evidence.

- Hydrate Decomposition: The hydrate decomposition behavior was assumed to proceed in the same manner as the decay of radioactive nuclide (see Equations 7-9); the constants in the decomposition rates were determined with experimental fitting. This kind of data fitting is not expected to be perfect, particularly at low temperature portions where it requires a long. period of time to complete decomposition measurements. The adequacy of the decomposition model will be evaluated with test results of whole element testing. As shown in Figure 2, it takes staging time of 1200 hours for the pressure rise in the canister to reach a maximum and level off. In this simulation, the decay heat is assumed to be $1.06 \mathrm{~W}$ in the normal case, the temperature is not high (less than $\left.70^{\circ} \mathrm{C}\right)$ and the hydrate decomposition rate is $10 \mathrm{w}$; as a result, the water released from hydrates has sufficient time to react with uranium to produce hydrogen. On the other hand, the hydrate decomposition rate increases rapidly during temperature ramp in constant temperature tests, causing a significant increase in water vapor pressure. In the meantime, hydrogen is also produced with the total pressure approaching a stable level. Gas samples extracted during whole element testing should provide useful information for understanding the decomposition models.

- Chemical Reaction: The pressure response in the fuel canister to chemical reactions is calculated on the basis of the reaction rate of uranium oxidation given in the open literature. In the staging tests, the pressure in the canister is predicted to increase slowly because of gas generation from chemical reactions under conditions of a sma11 temperature increase. Results of whole element tests are expected to compare favorably with those obtained from pressurization modeling. 
- Thermal Reaction: Uranium-water reactions are exothermic, i.e., heat is produced from these reactions in addition to decay heat. The heat produced by the reactions of water vapor and uranium may be so large that a thermal transient results. The answer is sought by performing post-drying tests on whole fuel elements:

Although whole element testing may provide convincing evidences to verify chemical reaction and hydrate decomposition models, some uncertainties in pressurization modeling for a much Targer fuel container like an MCo still cannot be eliminated. As 1isted in Table 2, the new best-estimate of a single element sludge content is $29 \mathrm{gm}$; this amount of sludge should produce a pressure of about $18 \mathrm{psi}$ in a fuel container (see Figure 11) or $43 \mathrm{psi}$ in the $\mathrm{MCO}$ at $150^{\circ} \mathrm{C}$. Such a low maximum pressure is we 11 below the design pressure of the MCO that was evaluated to be 150 psi (Huang 1997). Plots shown in Figures 5 through 12 clearly indicate that the pressure level in whole element canisters depends on water content and that the higher the temperature the faster the pressure in the container will peak because hydrate decomposition and chemical reaction rates increase with increasing temperature. Test results not on iy will indicate actual water content in each element but also. will show hydrogen generation and hydrate decomposition behavior. 
HNF-2047, Rev. 0

\subsection{CONCLUSION}

Modeling calculations are performed to support single element post CVD tests at temperatures from $50^{\circ} \mathrm{C}$ up to $150^{\circ} \mathrm{C}$. Results of the evaluations show that such tests are feasible and that the maximum pressure of the fuel canister increases with increasing water or sludge content. The time taken to reach the maximum pressure depends on the amount of heat generated from nuclear decay, chemical reactions, external supply, reaction area of damaged fue 1 , and reaction rate. The model predicts the pressure in the test container will level off in 10 days if the whole fuel element is heated at a constant temperature of about $110^{\circ} \mathrm{C}$. Even at the initial staging temperature of $50{ }^{\circ} \mathrm{C}$ the single element post CVD tests can be completed in a few months. These modeling results also provide basis for post-test evaluation of gas generation models, particularly the hydrate decomposition model that describes the behavior of water released from crystalline structures of uranium oxide at elevated temperatures. 
HNF-2047, Rev, 0

This page intentionally left blank. 
HNF-2047, Rev, 0

\subsection{REFERENCES}

Abrefah, J., et al., 1997, Drying Behavior of K-East Canister Sludge, Pacific Northwest National Laboratory, Richland, Washington.

Cooper, T. D., 1996, Gas Generation from N-Fuel in Multi-Canister Overpack, WHC-SD-SNF-TI-028, Rev. 0, Westinghouse Hanford Company, Richland, Washington.

Duncan, D. R., 1997, Spent Nuc7ear Fue7 Project Technical Databook, HNF-SD-SNF-TI-015, Rev. 2, Duke Engineering \& Services Hanford, Inc., Richland, Washington.

Fryer, B. C., M. J. Thurgood, and D. M. Ogden, 1996, MCO Pressurization Ana7ysis of Spent Nuclear Fue7 Transportation and Storage, WHC-SD-SNF-ER-014, Rev. 0, Westinghouse Hanford Company, Richland, Washington.

HNF, 1997, Sensitivity of CVDF to CSB Transport Conditions to Reaction Rates and Fuel Surface Area, HNF-SD-SNF-CN-007, Duke Engineering \& Services Hanford, Inc., Richland, Washington.

Huang, F., 1996, "Structural Evaluations of the Containment Vessel for Corroded Spent Nuclear Fuel," in Proceeding of Symposium on Natural Hazard Phenomena and Mitigation, Montrea1, Canada, PVP Vo1. 330, pp. $75-81$.

Lawrence, L. A., 1997a, Strategy for Examination of Fifteen $K$ West Basin Fue 7 ETements, HNF-SD-SNF-SP-018, Rev. 0, Duke Engineering \& Services Hanford, Inc., Richland, Washington.

Lawrence, L. A., et aT., 1997b, Estimates of the Reactive Fuel Surface Area in a Multi-Canister Overpack for Use in Process and Safety Calculations, HNF-SD-SNF-CN-017, Rev: 0, Duke Engineering \& Services Hanford, Inc., Richland, Washington.

Makenas, B. J., et a7., 1997, Analysis of S7udge from Hanford K East Basin Canisters, HNF-SP-1201, Duke Engineering \& Services Hanford, Inc., Richl and, Washington.

Pajunen; A. L., 1997, Estimated Fuel Inventory Loaded in Fuel and Scrap Basket, HNF-SD-SNF-CN-012, Rev. 0, Duke Engineering \& Services Hanford, Inc., Richland, Washington.

Pearce, K. L., 1989, "A Review of Rates of Reaction of Unirradiated Uranium in Gaseous Atmospheres," Report RD/B/6231/R89, Central Electricity Generating Board, Berkeley Nuclear Laboratories, Berkeley, England. 


\subsection{REFERENCES (Continued)}

Pitner, A. L., 1995, K East Basin Underwater Visual Fuel Surway, WHC-SD-SNF-TI-012, Rev. 0, Westinghouse Hanford Company, Richland, Washington.

Pitner, A. L., 1997, K Basin Fuel Subsurface Examinations and Surface Coating Sampling, HNF-SD-SNF-TI-060, Rev. 0, Duke Engineering \& Services Hanford, Inc., Richland, Washington.

Plys, M. G., 1997, "Hydrate Decomposition: Parameter Investigation, "Fauske \& Associates, Inc.

Sloughter, J., et a1., 1997, "Expert Judgement Estimates of Particulate Mass Loaded Into a Muiti-Canister Overpack," Appendix A in FAI/97-90, Rev. 1, Fauske \& Associates, Inc.

WHC, 1995, Integrated Process Strategy for $K$ Basins Spent Nuclear Fuel, WHC-SD-SNF-SP-005, Rev. 0, Westinghouse Hanford Company, Rich7 and, Washington. 
HNF-2047, Rev. 0

Figure 1. Canister Pressure During Staging for a Fuel Element with $40 \mathrm{gm}$ of Sludge and Decay Heat of 2.07 Watts.

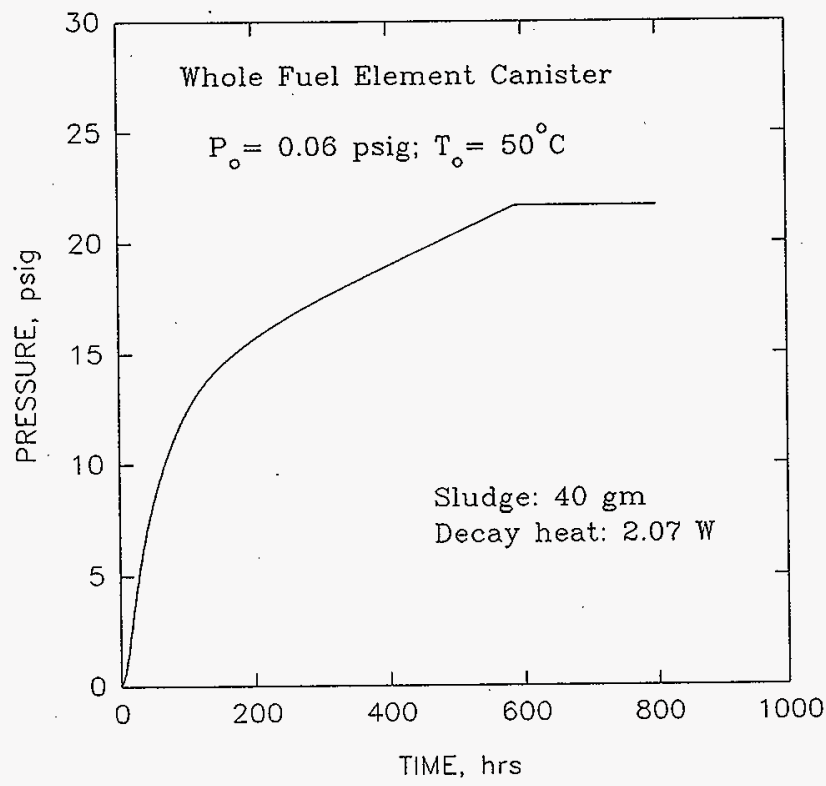


Figure 2. Canister Pressure During Staging for a Fuel Element with $40 \mathrm{gm}$ of Sludge and Decay Heat of 1.06 Watts.

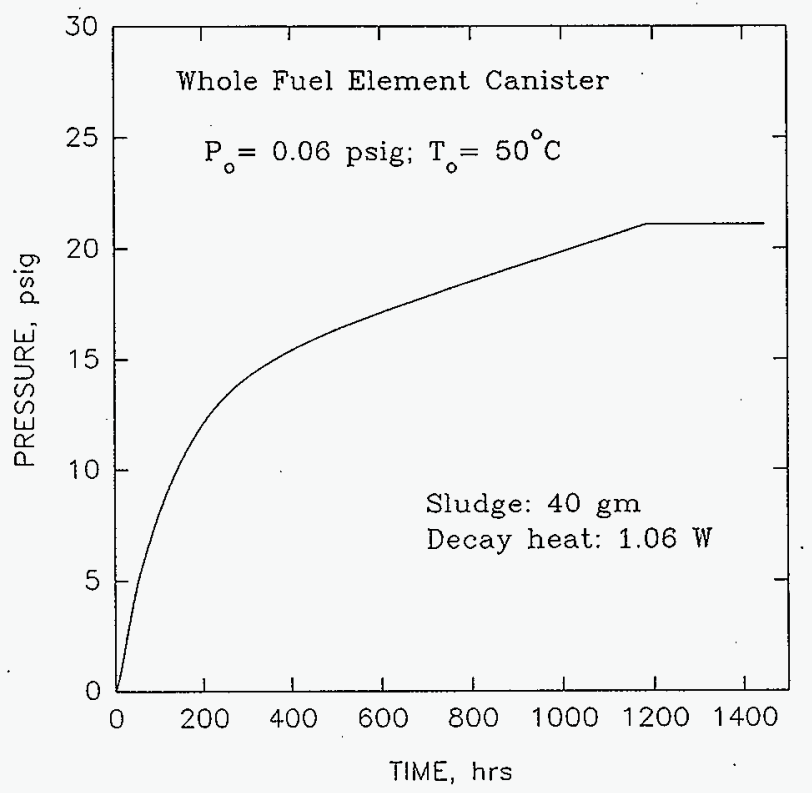


HNF-2047, Rev. 0

Figure 3. Canister Temperature During Staging for a Fuel Element with $40 \mathrm{gm}$ of Sludge and Decay Heat of 2.07 Watts.

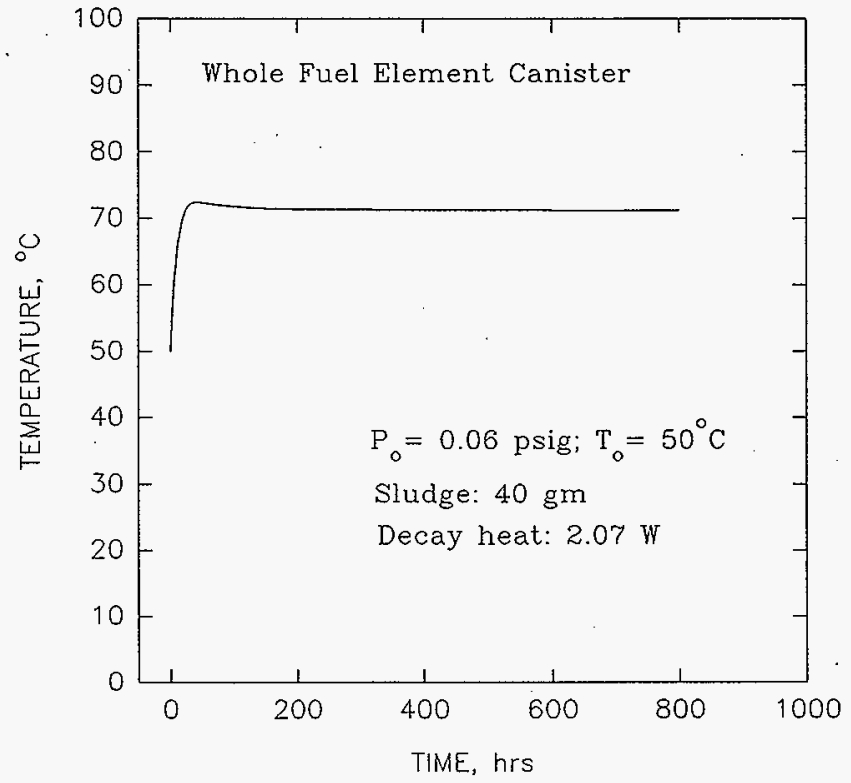


HNF-2047, Rev. 0

Figure 4. Canister Temperature During Staging for a Fuel Element with $40 \mathrm{gm}$ of Sludge and Decay Heat of 1.06 Watts.

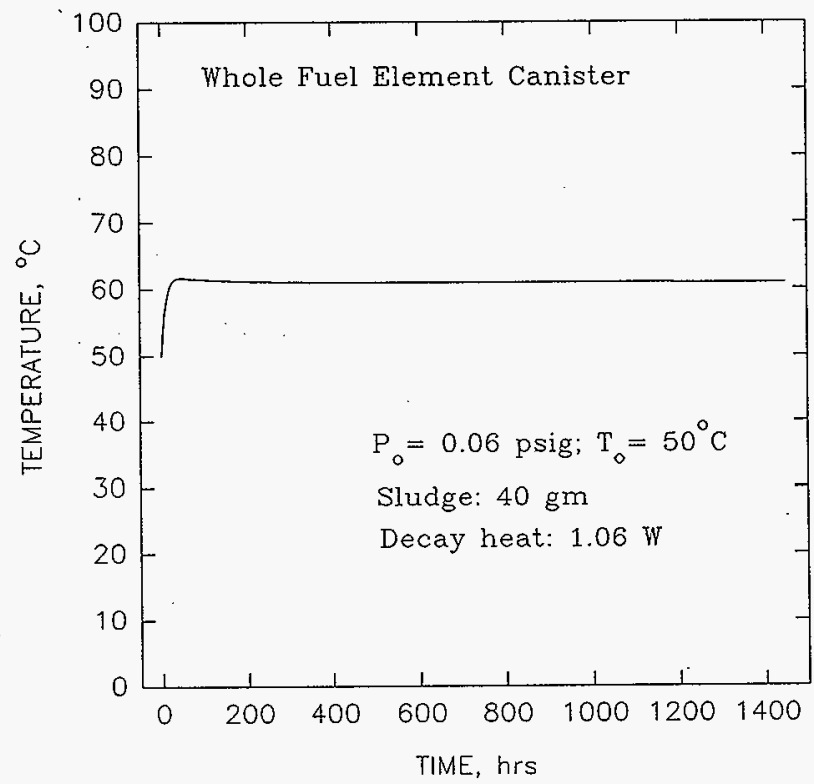


Figure 5. A Comparison Between Canister Pressures at Constant Temperatures of $85^{\circ} \mathrm{C}$ for $40 \mathrm{gm}$ and $20 \mathrm{gm}$ S7udge Contents.

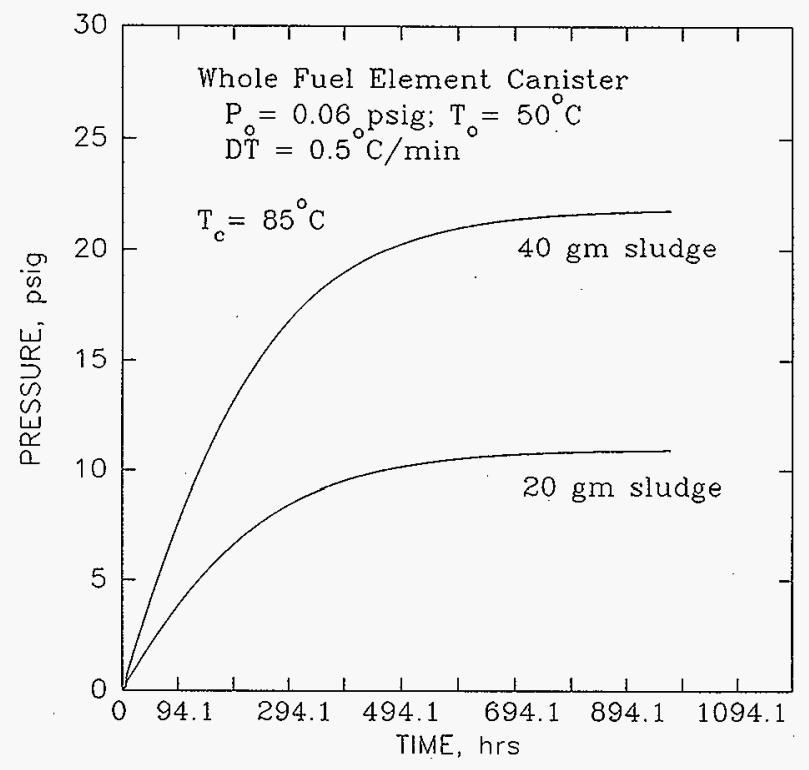


HNF-2047, Rev. 0

Figure 6. A Comparison Between Canister Pressures at Constant Temperatures of $85{ }^{\circ} \mathrm{C}$ for $10 \mathrm{gm}$ and $5 \mathrm{gm}$ Sludge Contents.

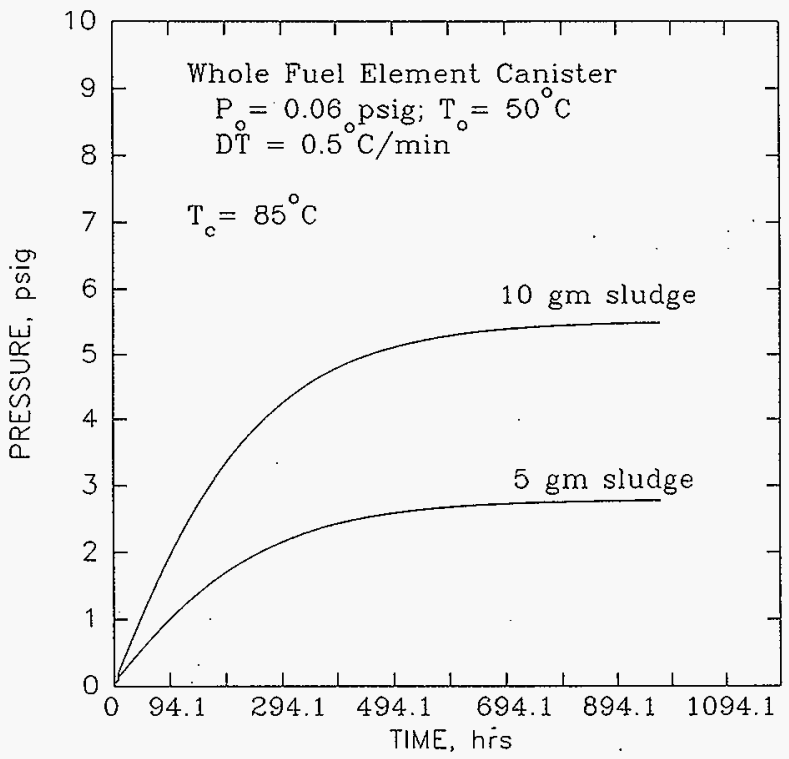


Figure 7. A Comparison Between Canister Pressures at Constant Temperatures of $105{ }^{\circ} \mathrm{C}$ for $40 \mathrm{gm}$ and $20 \mathrm{gm}$ Sludge Contents.

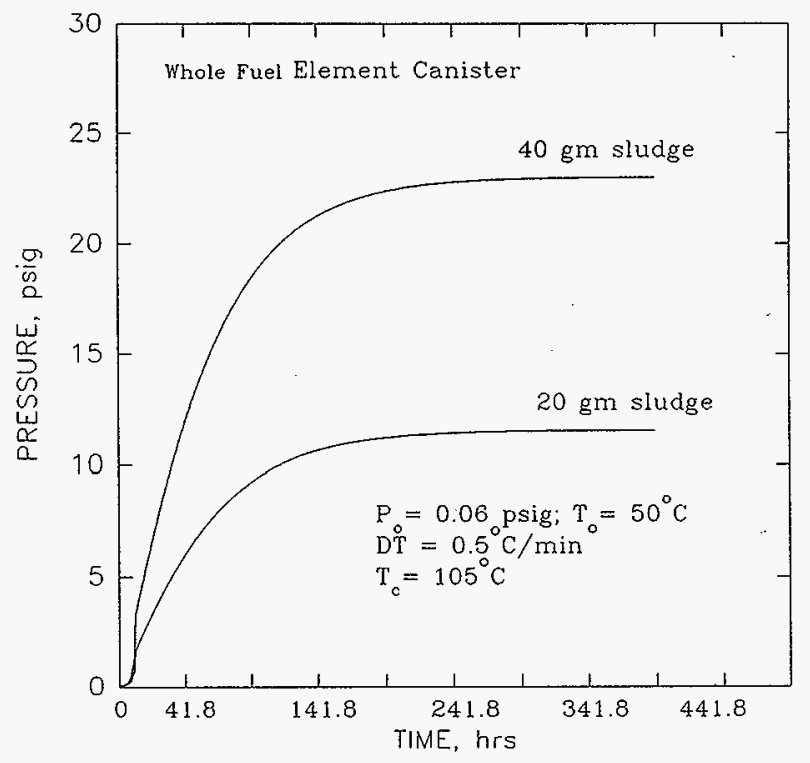


HNF-2047, Rev. 0

Figure 8. A Comparison Between Canister Pressures at Constant Temperatures of $105^{\circ} \mathrm{C}$ for $10 \mathrm{gm}$ and $5 \mathrm{gm}$ Sludge Contents.

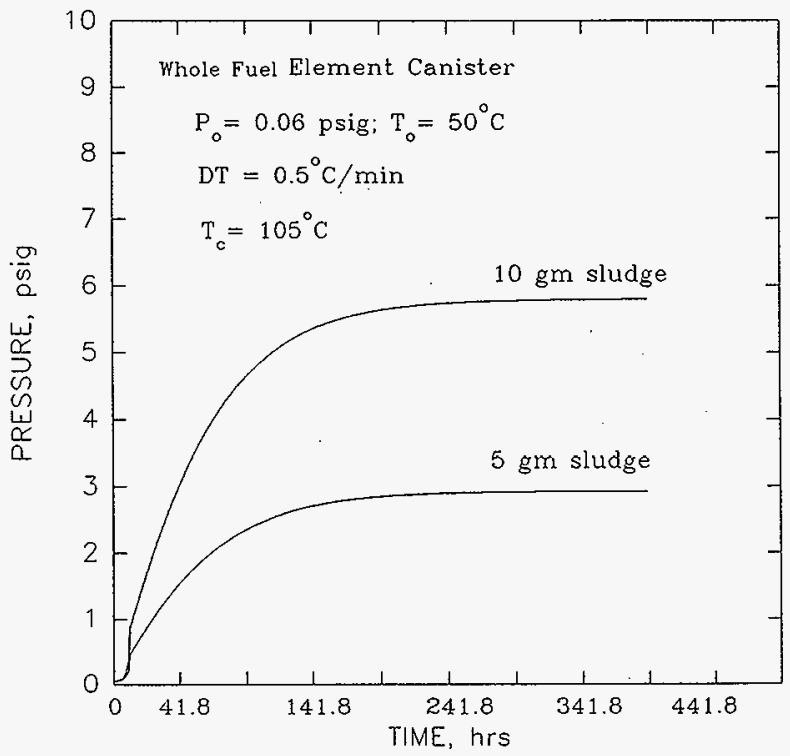


HNF-2047, Rev. 0

Figure 9. A Comparison Between Canister Pressures at Constant Temperatures of $125^{\circ} \mathrm{C}$ for $40 \mathrm{gm}$ and $20 \mathrm{gm}$ Sludge Contents.

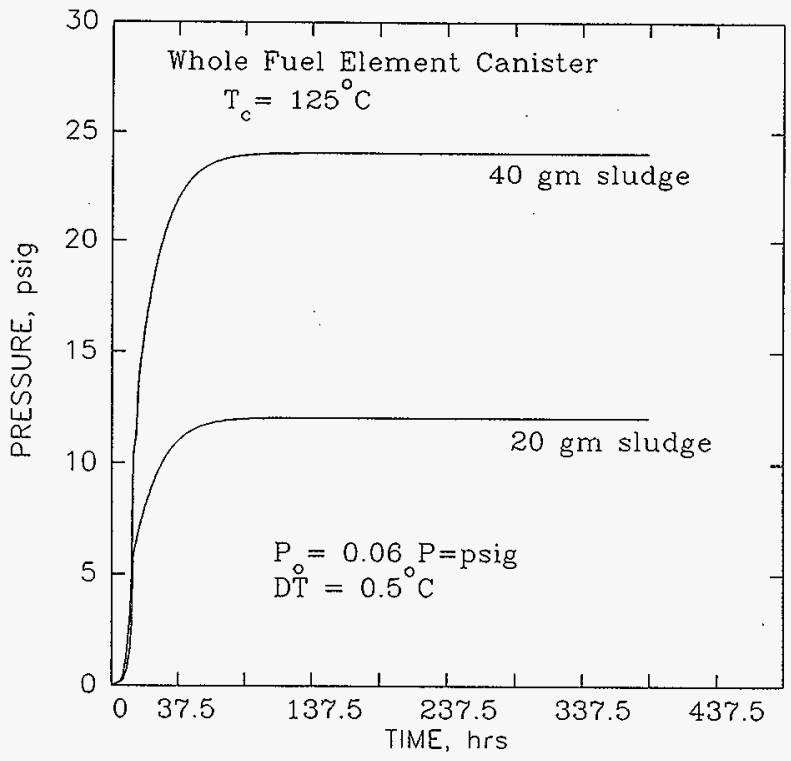


HNF-2047, Rev. 0

Figure 10. A Comparison Between Canister Pressures at Constant Temperatures of $125^{\circ} \mathrm{C}$ for $10 \mathrm{gm}$ and $5 \mathrm{gm}$ Sludge Contents.

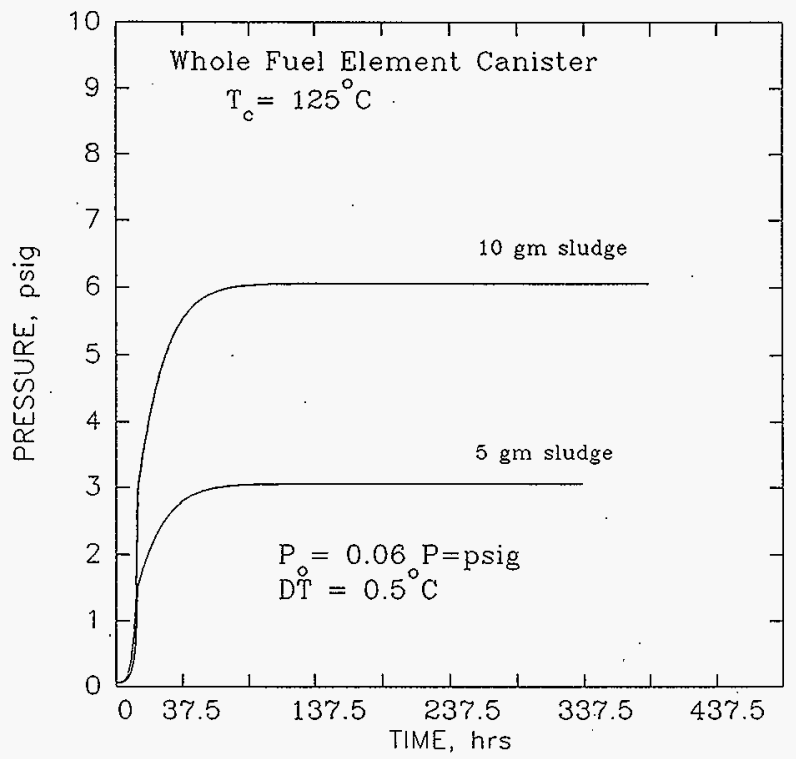


HNF-2047, Rev. 0

Figure 11. A Comparison Between Canister Pressures at Constant Temperatures of $150^{\circ} \mathrm{C}$ for $40 \mathrm{gm}$ and $20 \mathrm{gm}$ STudge Contents.

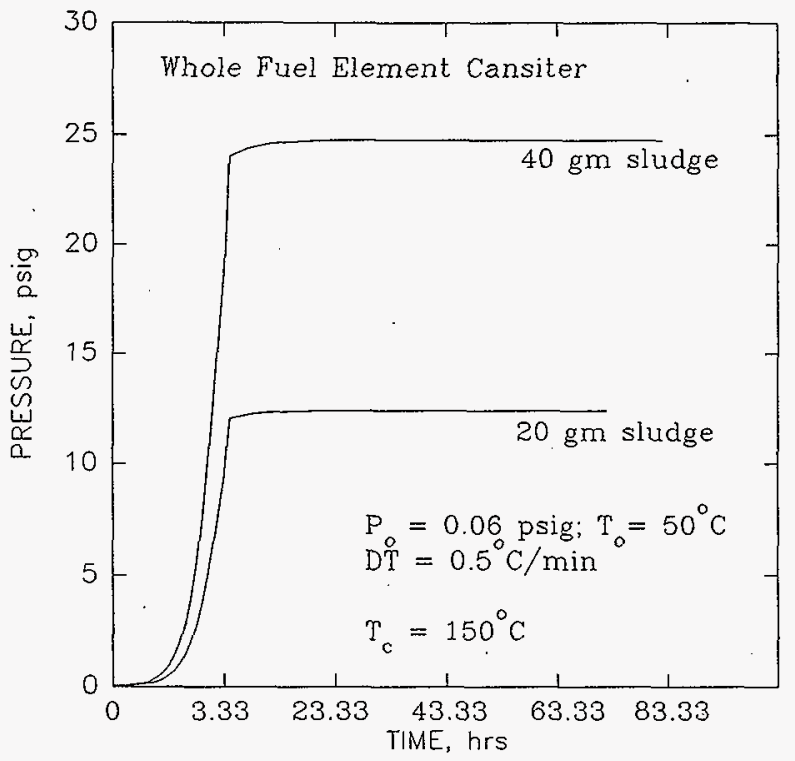


HNF-2047, Rev. 0

Figure 12. A Comparison Between Canister Pressures at Constant Temperatures of $150^{\circ} \mathrm{C}$ for $10 \mathrm{gm}$ and $5 \mathrm{gm}$ Sludge Contents.

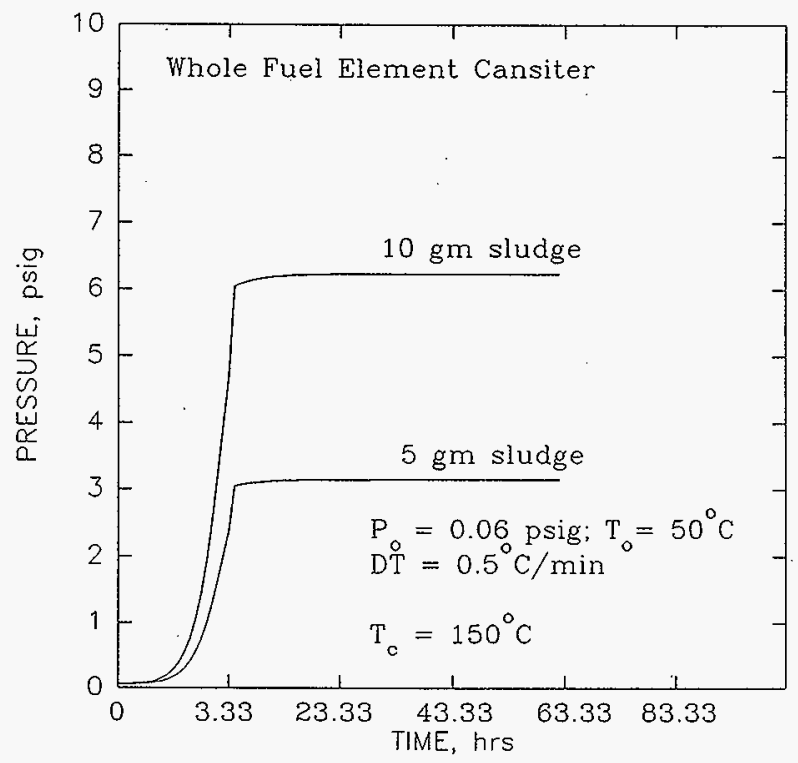




\section{DISTRIBUTION SHEET}

\begin{tabular}{|c|c|c|c|c|c|}
\hline To & \multirow{2}{*}{\multicolumn{3}{|c|}{$\begin{array}{l}\text { From } \\
\text { Spent Nuclear Fuel } \\
\text { Characterization/2T720 }\end{array}$}} & \multicolumn{2}{|l|}{ Page 1 of 2} \\
\hline Distribution & & & & \multicolumn{2}{|c|}{ Date $01 / 7 / 97$} \\
\hline \multirow{2}{*}{\multicolumn{3}{|c|}{$\begin{array}{l}\text { Project Title/Work Order } \\
\text { Spent Nuclear Fuel Project }\end{array}$}} & & \multicolumn{2}{|c|}{ EDT No. 615131} \\
\hline & & & & \multicolumn{2}{|l|}{ ECN No. } \\
\hline Name & MSIN & $\begin{array}{l}\text { Text } \\
\text { With All } \\
\text { Attach. }\end{array}$ & Text Only & $\begin{array}{l}\text { Attach./ } \\
\text { Appendix } \\
\text { Only }\end{array}$ & $\begin{array}{c}\text { EDT/ECN } \\
\text { Only }\end{array}$ \\
\hline
\end{tabular}

4 DOE Richland Operation Office

Hiegel, RM

Loscoe, PG

S7-41

Sellers, ED

Shuen, J-S

S7-41

S7-41

S7-41

14 D\&ES Hanford, Inc.

$\begin{array}{ll}\text { Baker, RB } & H 0-40 \\ \text { Chastain, SA } & H 0-40 \\ \text { Cowan, RG } & \text { R3-86 } \\ \text { Duncan, DR } & \text { R3-86 } \\ \text { Frederickson, JR } & \text { R3-86 } \\ \text { Lawrence, LA(2) } & H 0-40 \\ \text { LeRoy, PG } & \text { R3-11 } \\ \text { Makenas, BJ } & \text { HO-40 } \\ \text { Omberg, RP } & H 0-40 \\ \text { Rasin, WH } & \text { R3-11 } \\ \text { Swenson, JA } & \text { R3-11 } \\ \text { Trimble, DJ } & \text { H0-40 }\end{array}$

SNF Project Files

1 SGN Eurisys Services Corp

$\begin{array}{ll}\text { Pajunen, AL R3-86 } & \text { AL }\end{array}$

1 Fluor Daniel Hanford

Gerber, EW R3-86

4 Fluor Daniel Northwest

Garvin, LJ

Huang, FF

Ritter, GA

Smith, DA

H5-70

E6-15

HO-31

R3-11 


\begin{tabular}{|c|c|c|c|c|c|}
\hline \multicolumn{6}{|c|}{ DISTRIBUTION SHEET } \\
\hline To & \multirow{2}{*}{\multicolumn{3}{|c|}{$\begin{array}{l}\text { From } \\
\text { Spent Nuclear Fuel } \\
\text { Characterization/2T720 }\end{array}$}} & \multicolumn{2}{|l|}{ Page 2 of 2} \\
\hline Distribution & & & & \multicolumn{2}{|c|}{ Date $01 / 7 / 97$} \\
\hline \multicolumn{4}{|l|}{ Project Title/Work Order } & \multicolumn{2}{|c|}{ EDT No. 615131} \\
\hline Spent Nuclear Fuel Project & & & & \multicolumn{2}{|l|}{ ECN No. } \\
\hline Name & MSIN & $\begin{array}{c}\text { Text } \\
\text { With All } \\
\text { Attach. }\end{array}$ & Text Only & $\begin{array}{l}\text { Attach./ } \\
\text { Appendix } \\
\text { Only }\end{array}$ & $\begin{array}{c}\text { EDT/ECN } \\
\text { Only }\end{array}$ \\
\hline
\end{tabular}

7 Numatec Hanford Company

Chevrier, GP R3-86

Cramer, ER HO-34

Flament, TA R3-86

Irwin, JJ R3-86

Miska, CR R3-86

Sloughter, JP H5-49

Thurgood, MJ

2 Technica] Advisory Group

DeVine, JC R3-82

Williams, RF S7-41

2 Pacific Northwest National Laboratory

Abrefah, J P7-27

Marschman, SC P7-27

Central Files B1-07 